\title{
In-vitro evaluation of the effects of insertion and sterilization procedures on the mechanical and surface characteristics of mini
} \section{screws}

\section{Purpose}

The aim of the present study was to investigate the effects of insertion and sterilization on primary stability and to examine the mechanical and surface characteristics of mini screws.

\section{Materials and methods}

140 miniscrews (70 Dual-Top; 70 Ortho-Easy) were divided into 3 groups. Group 1: control group, 10 miniscrews of each brand, evaluated without any primary procedure. Group 2: 30 miniscrews of each brand, each inserted into the sawbone once, then sterilized and tested. Group 3: 30 miniscrews of each brand, each inserted into the sawbone twice, sterilized after each insertion and then tested. The miniscrews were evaluated for changes in primary stability, mechanical and surface characteristics with scanning electron microscopy (SEM) analysis, torsion tests, maximum insertion-removal torques and vertical-horizontal pull out strength tests.

\section{Results}

The maximum insertion torque values of the unused miniscrews (Group 1) were found to be significantly higher than those of the reused (Groups 2,3) mini screws $(p<0.05)$. Removal torque, vertical-horizontal pull-out strength and torsional strength value changes were found to be statistically insignificant. In SEM analysis, wear and atrophy were seen on the threads of used miniscrews especially in the apical region and the oxide layer was seen to have disappeared from some regions of the coated miniscrews.

\section{Conclusion}

Although wear and atrophy were detected in SEM analysis of used miniscrews, the overall primary stability and fracture torque resistance tests did not show any significant changes after the first and second insertion and sterilization procedures.

Keywords: Miniscrew; orthodontic mini-implant; primary stability; scanning electron microscope; sterilization

\section{Introduction}

Anchorage is defined as the resistance to unwanted tooth movement and anchorage control is the key factor in successful orthodontic treatment (1). Before skeletal anchorage devices, clinicians tried many kinds of mechanics to obtain better anchorage via intraoral and extra oral devices. However, the success of these treatments is greatly affected by patient discomfort, the need for patient cooperation and side effects $(2,3)$. The idea of skeletal anchorage for orthodontic purposes arose from the need to eliminate anchorage losses and patient compliance problems. Gainsforth and Higley (4) performed the first successful application of skeletal anchorage in the mid-1940s with vitalium implants. In 1997, Kanomi (5) introduced first

\author{
Civan Aved Hergel', \\ Yasemin Bahar Acar², \\ Mustafa Ateş ${ }^{1}$, \\ Nazan Küçükkeleş ${ }^{1}$
}


mini-implants designed for orthodontic anchorage. With developments in design and material, the miniscrews have become one of the most common skeletal anchorage devices, owing to simple placement, patient comfort and immediate loading capabilities. However, one important issue with miniscrews is that they can become loose due to their nonosseointegrated structure and immediate loading capability. Therefore, the primary stability, the stability immediately after insertion in bone, is crucial for the success of mini screws (5).

Miniscrews can be applied to almost every region of the mouth and can be used for many kinds of mechanics $(6,7)$. As the application process is very easy and well accepted by patients, clinicians can move miniscrews to different regions of the mouth according to anchorage needs (8). Sterilization and recycling of orthodontic materials such as stainless steel braces or nickel titanium archwires have been documented in orthodontic practice. Buckthal and Kusy reported that 52\% of clinicians recycle nickel-titanium wires to reduce the costs of orthodontic treatment (9). Some studies have shown that sterilization and recycling have no effect on the mechanical properties of orthodontic wires or braces, while others have shown mechanical or surface alterations (10-12). Like wires and braces, the recycling of miniscrews, although not well documented, is an issue in orthodontic practice.

In a survey carried out in Turkey in $2014,41 \%$ of participants replied that they were using miniscrews more than once (13). Although the recycling and reuse of invasive materials may create an ethical concern and should not be encouraged, reinsertion of a miniscrew can be considered in the same patient (especially in cases of early failure, they can be re-inserted in a different location), if sterilization and previous insertion processes do not create any alteration in mechanical properties. Reports on this subject have shown conflicting results. Mattos et al. (8) found that in used miniscrews, the resistance to torsional forces was decreased and therefore the reuse of miniscrews was not recommended. In contrast, Noorollahian et al. (14). investigated insertion, removal and fracture torque differences between used and non-used miniscrews and found that insertion into bone and processing with $37 \%$ phosphoric acid for 10 minutes and $5.25 \%$ sodium hypochlorite for 30 minutes and re-sterilization with autoclave, had no adverse effects on insertion, removal, and fracture torque values. Estelita et al. (15) also demonstrated no change in torsional strengths of screws that had undergone recycling protocols

The aim of this study was to investigate the effects of insertion and sterilization on primary stability, mechanical and surface characteristics of miniscrews via SEM analysis, torsion tests, maximum insertion-removal torques and verticalhorizontal pull out strength tests, and thus, to evaluate the viability of reusing miniscrews.

\section{Materials and methods}

140 miniscrews from two different brands were used for the study (70 DualTop G2, Jeil Medical, Seul, South Corea; 70 OrthoEasy, Forestadent, Pforzheim, Germany). Both miniscrews were cylindrical in shape (DualTop miniscrews:1.6 x $8 \mathrm{~mm}$; OrthoEasy miniscrews 1.7 x $8 \mathrm{~mm}$ ). The miniscrews

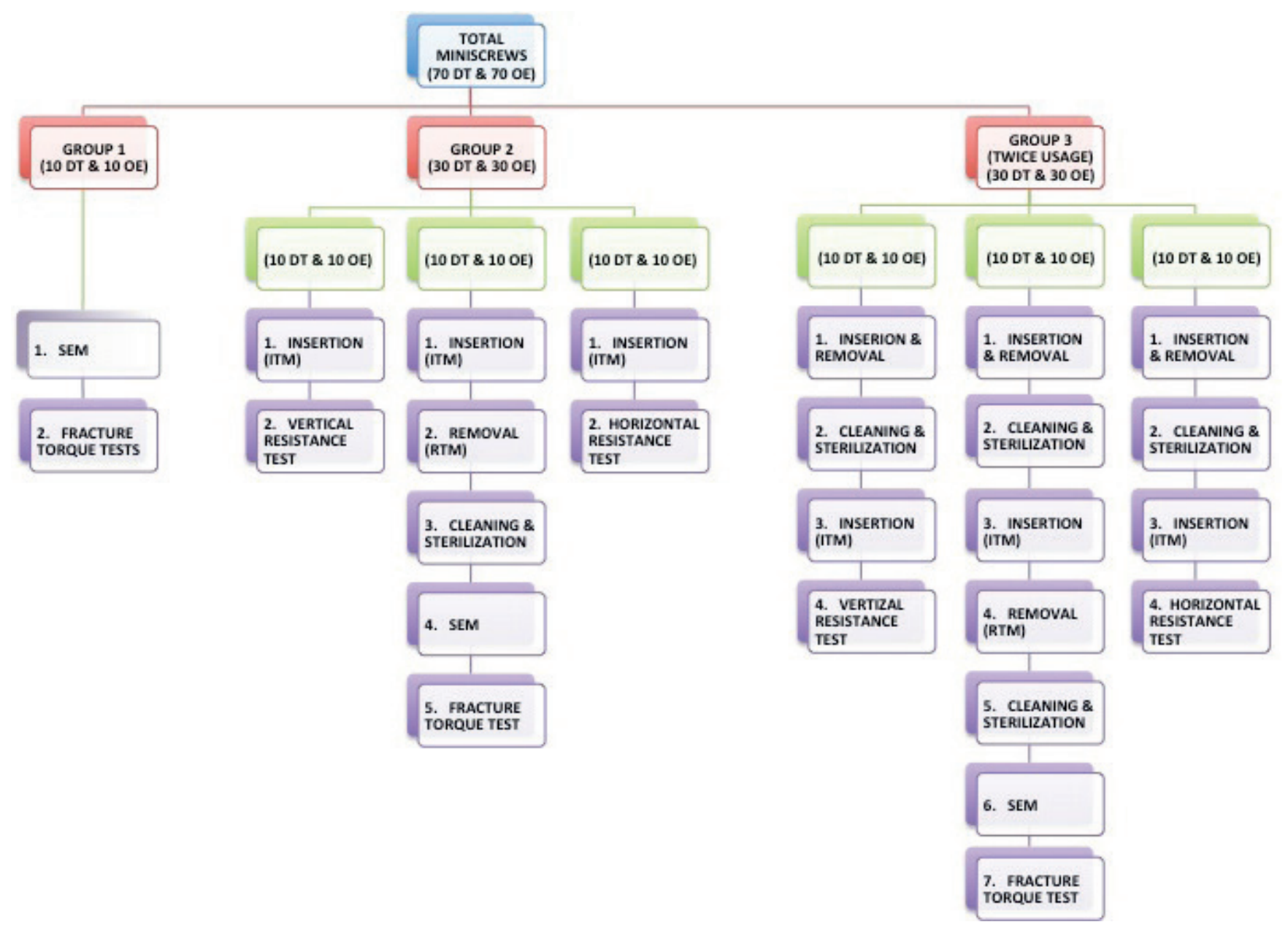

Figure 1. Contents and procedures of groups. 

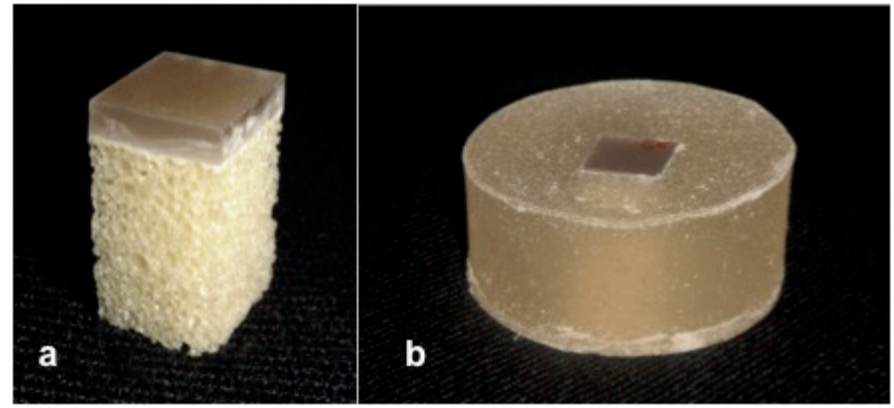

Figure 2. a) Sawbone artificial bone material; b) Sawbone embedded in acrylic resin.

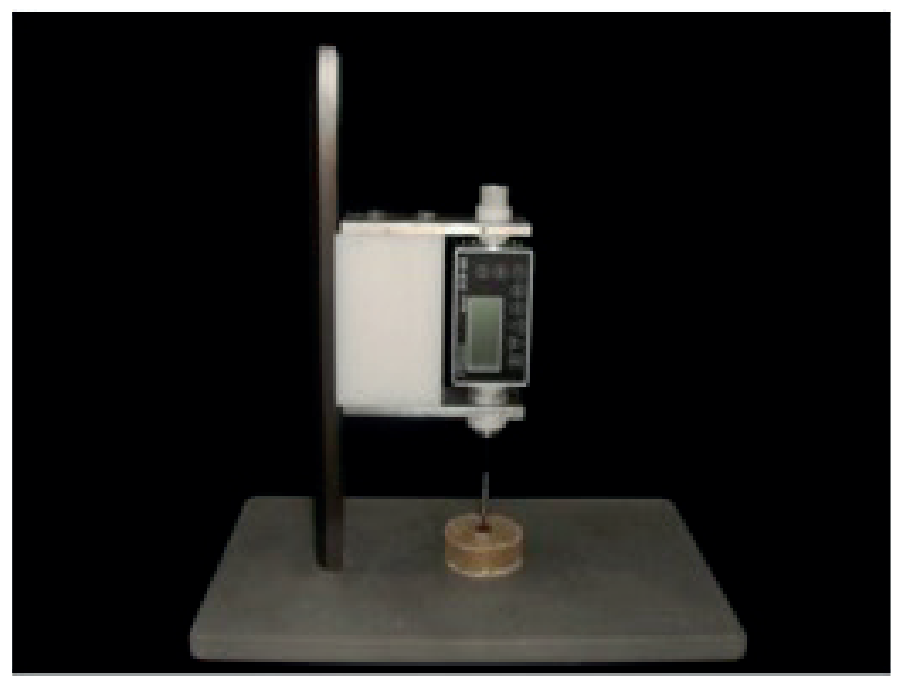

Figure 3. Cedar DID-05 digital torque-screwdriver.

were divided into 3 groups. Group 1 was the control group and consisted of 10 miniscrews of each type. They were evaluated as they were received, without any primary procedure and without insertion into the sawbone. Groups 2 and 3 were experimental groups, consisting of 30 miniscrews of each type. Group 2 was inserted into the sawbone once, then sterilized and tested. Group 3 was inserted into the sawbone twice, sterilized after each insertion and then tested. The same researcher repeated all the procedures 1 month later. The contents and procedures of the groups are schematically shown in Figure 1. Sawbone artificial bone material was used for experiments (Sawbone Europe AB, Malmö, Sweden). A short-fiber filled epoxy sheet ( $2 \mathrm{~mm}$ thickness; representing cortical bone) was attached to a $20-p c f\left(0.32 \mathrm{~g} / \mathrm{cm}^{3}\right)$ cellular rigid polyurethane foam block (10mm thickness; representing cancellous bone) with $3 \mathrm{M}$ acrylate bond (Figure 2). For the specimens to be compatible with the Instron machine, the artificial bone material was divided into $1 \times 1 \times 2.2 \mathrm{~cm}$ sized pieces and were embedded into acrylic resin under watercooling. The uniformity of the blocks was checked with a water gauge and each sample was given a number. Retention grooves were drilled on the epoxy sheet to preserve material integrity during the tests.

\section{Maximum insertion and removal torque measurements}

Insertions of mini screws were performed using a Cedar DID-05 digital torque screwdriver (Checkline Europe

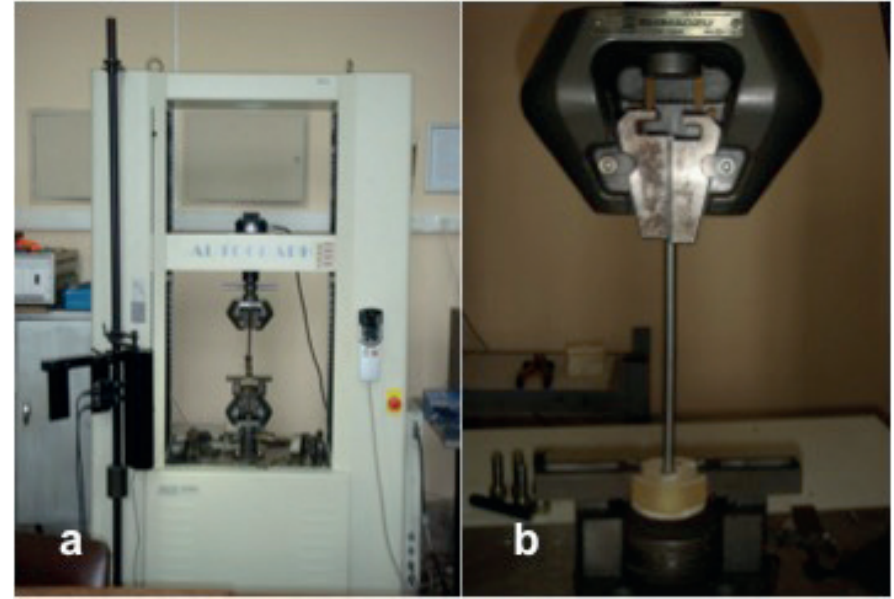

Figure 4. a) Schimatzu AG-IC Instron machine; b) Vertical resistance test mechanism of DualTop miniscrews.

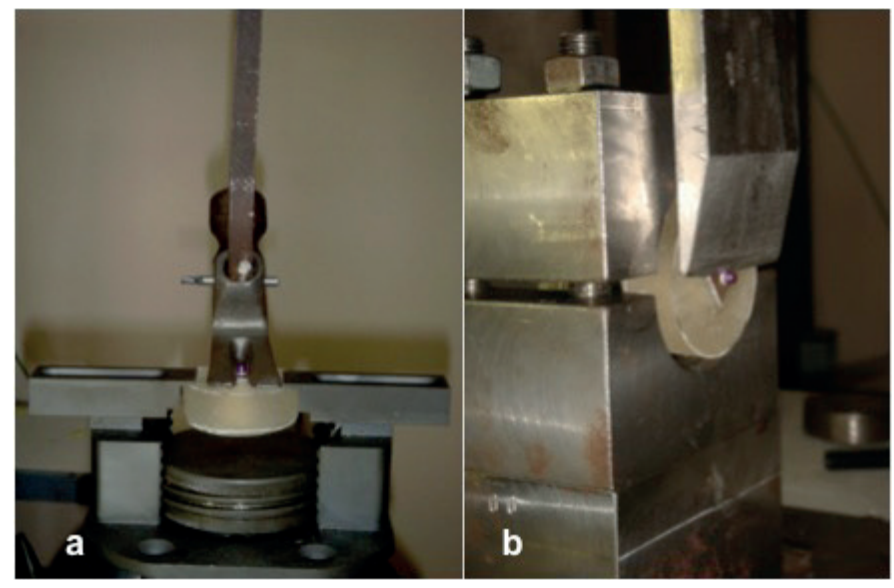

Figure 5. a) Vertical resistance test mechanism of OrthoEasy miniscrews; b) Horizontal resistance test mechanism.

GmbH\&Co.KG, Gronau, Germany). To place the miniscrews perpendicular to the artificial bone, a special apparatus was used (Figure 3). With this apparatus, the angulation of the torque-meter was fixed and could not be changed. The torque-meter could only move vertically and rotate around its axis. The miniscrews were inserted with the digital torquemeter until a $1.2 \mathrm{~mm}$ gap was left between the bone and the head of the miniscrews and the peak values of torques were recorded. Removal of 20 miniscrews from each group was applied with the same screwdriver and peak values were recorded.

\section{Vertical and Horizontal Resistance Tests}

Horizontal and vertical resistance tests were performed using a Schimatzu AG-IC Instron machine (Schimatzu Co., Tokyo, Japan) (Figure 4a). For vertical resistance tests of DualTop miniscrews, a $0.8 \mathrm{~mm}$ round wire was passed through the hole of the miniscrew (Figure 4b). For vertical resistance tests of OrthoEasy miniscrews, a notched device was passed under the head of the screw, since OrthoEasy miniscrews do not have holes on the head (Figure 5a). For horizontal resistance tests a knife-like device was applied to the heads of the miniscrews (Figure 5b). The force value of $0.6 \mathrm{~mm}$ displacement of the head was recorded. 


\section{Cleaning and sterilization}

Miniscrews that were to be examined with SEM after insertion into the sawbone, were first cleaned of debris with a Codyson CD-3800A ultrasonic cleaner (Codyson Electrical Co. Ltd., Shenzhen, China) for 30 minutes and rinsed. Cleaning solution was prepared using $1 \mathrm{lt}$ distilled water and $5 \mathrm{ml}$ Endozyme (Ruhof Co., Long Island, New York, USA). Then, each miniscrew was packed separately, sterilized at $135^{\circ} \mathrm{C}$ for 10 min and dried for 55 min with Statim 7000 (SciCan Ltd., Toronto, Canada).

\section{Scanning Electron Microscopy Examinations}

Scanning electron microscopy examinations were performed with JEOL JSM-5910LV(JEOL Ltd. Tokyo, Japan) and Energy scatter spectrometer INCAx-sight 7274 (OXFORD Industries, England) with 133-eV resolution. Images of 10 miniscrews (5 DT, $5 \mathrm{OE}$ ) from each group were taken at 20x, 40x, 100x, 200x, 500x, 1000x, 2000x, 5000x and 10000x magnifications to examine surface modifications.

\section{Fracture Torque Tests}

To understand torsional strength differences between the non-used and re-used miniscrews, fracture torque tests were applied. A $10 \mathrm{~mm}$ thick cortical bone layer of bovine femur bone was used for these tests. The miniscrews were inserted in the bones until breaking point. Peak torque value before fracture was recorded.

\section{Statistical Analysis}

SPSS for Windows 15.0 (SPSS, Chicago, III) software was used for statistical analyses. The Kolmogorov-Smirnov test was used to evaluate normal distribution of data. To evaluate intergroup parameters of normally distributed data, the Student's t test and One-way Anova test were used. To evaluate intergroup parameters of non-normally distributed data, the Kruskal Wallis and Mann Whitney $U$ tests were used. The group that caused the difference was identified with the Mann Whitney $U$ test. Pearson Correlation analysis was used to evaluate the relationships of parameters. Data reliability was assessed by intraclass correlation coefficient (ICC). The results were evaluated at a statistical significance level of $\mathrm{p}<0.05$ and a $95 \%$ confidence interval.

\section{Results}

The insertion and removal torque values of Group 2 and 3 are shown in Table 1. The insertion torque values of Group 2 were significantly higher than those of Group 3. A decrease was determined in the removal torque values of Group 3, but this difference was not statistically significant.

The vertical and horizontal resistance values of Groups 2 and 3 are shown in Table 2. There was no statistically significant difference in the vertical and horizontal resistance values between Groups 2 and 3 in the DualTop miniscrews. The vertical resistance value changes of Groups 2 and 3 in the OrthoEasy miniscrews were also statistically insignificant, but the horizontal resistance of Group 3 in the OrthoEasy miniscrews was significantly higher than that of Group 2 OrthoEasy miniscrews.

The fracture torque values of all the groups are shown in Table 3. There was no difference between the groups in respect of fracture torque values.

SEM examinations showed noticeable wear in the used miniscrews. (Figure 6,7) Wear was increased in Group 3. The same operator repeated all the tests 1 month later. ICC was found to be close to 1.00 .

Table 1: Insertion and removal torque values ( $\mathrm{Ncm}$ ) for DualTop and OrthoEasy miniscrews in Group 2 and Group 3

\begin{tabular}{|c|c|c|c|c|c|c|}
\hline & & \multirow{2}{*}{$\frac{\text { Group II }}{\mathrm{n}}$} & \multicolumn{3}{|c|}{ Group III } & \multirow{2}{*}{$\mathbf{p}$} \\
\hline & & & Mean \pm SD & $\mathbf{n}$ & Mean \pm SD & \\
\hline \multirow{2}{*}{ Dual Top } & InsertionTorque & 30 & $26.98 \pm 0.68$ & 30 & $26.57 \pm 0.47$ & $0.011^{*}$ \\
\hline & RemovalTorque & 10 & $24.32 \pm 0.33$ & 10 & $24.18 \pm 0.33$ & 0.370 \\
\hline \multirow{2}{*}{ OrthoEasy } & InsertionTorque & 30 & $47.48 \pm 0.37$ & 30 & $47.17 \pm 0.44$ & $0.004^{* *}$ \\
\hline & RemovalTorque & 10 & $32.28 \pm 0.33$ & 10 & $32.17 \pm 0.40$ & 0.511 \\
\hline
\end{tabular}

Table 2: Vertical and horizontal resistance values (N) for DualTop and OrthoEasy miniscrews in Group 2 and Group 3

\begin{tabular}{|c|c|c|c|c|c|c|}
\hline & & \multirow{2}{*}{$\begin{array}{c}\text { Group II } \\
\mathbf{n}\end{array}$} & \multicolumn{3}{|c|}{ Group III } & \multirow[t]{2}{*}{$\mathbf{p}$} \\
\hline & & & Mean \pm SD & $\mathbf{n}$ & Mean \pm SD & \\
\hline \multirow{2}{*}{ Dual Top } & Horizontal Resistance & 10 & $518.05 \pm 67.15$ & 9 & $529.90 \pm 26.07$ & 0.626 \\
\hline & Vertical Resistance & 9 & $174.60 \pm 43.87$ & 10 & $203.27 \pm 14.58$ & 0.092 \\
\hline \multirow{2}{*}{ OrthoEasy } & Horizontal Resistance & 9 & $591.32 \pm 99.55$ & 10 & $589.06 \pm 47.28$ & 0.952 \\
\hline & Vertical Resistance & 10 & $270.21 \pm 65.47$ & 10 & $319.76 \pm 22.97$ & $0.045^{*}$ \\
\hline
\end{tabular}


Table 3: Fracture torque values for DualTop and OrthoEasy

miniscrews according to the groups

\begin{tabular}{lcccc}
\multirow{2}{*}{ FractureTorque } & \multicolumn{2}{c}{ Dual Top } & \multicolumn{2}{c}{ OrthoEasy } \\
\cline { 2 - 5 } & $\mathbf{n}$ & Mean \pm SD & $\mathbf{n}$ & Mean \pm SD \\
\hline Group I & 10 & $33.67 \pm 1.44$ & 10 & $29.04 \pm 0.39$ \\
\hline Group II & 10 & $33.73 \pm 1.11$ & 10 & $29.11 \pm 0.41$ \\
\hline Group III & 10 & $33.60 \pm 1.44$ & 10 & $28.98 \pm 0.57$ \\
\hline $\mathrm{p}$ & & 0.976 & & 0.817 \\
\hline
\end{tabular}

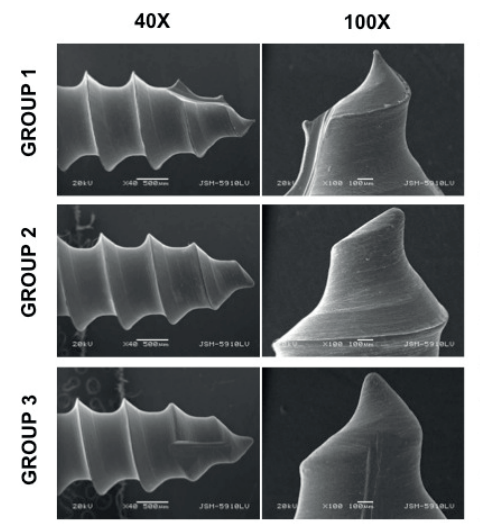

DUAL TOP

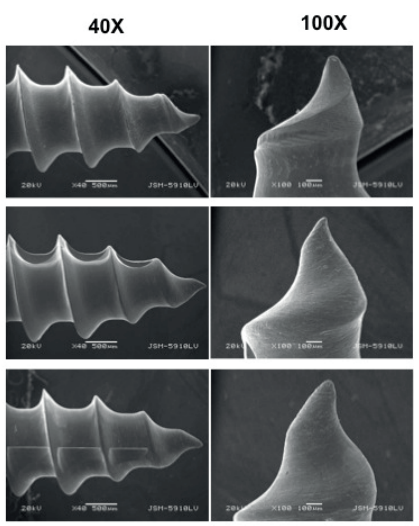

ORTHO EASY
Figure 6. SEM images (40x and 100x magnification).

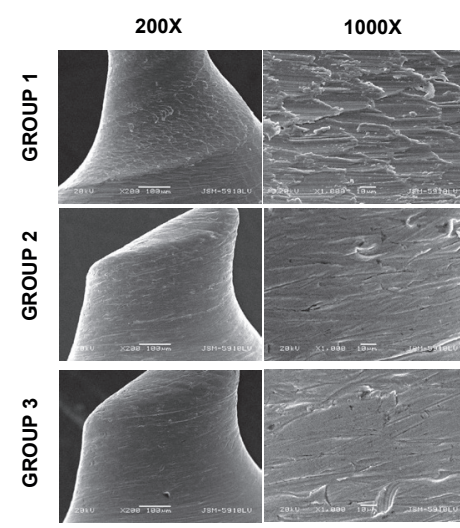

DUAL TOP

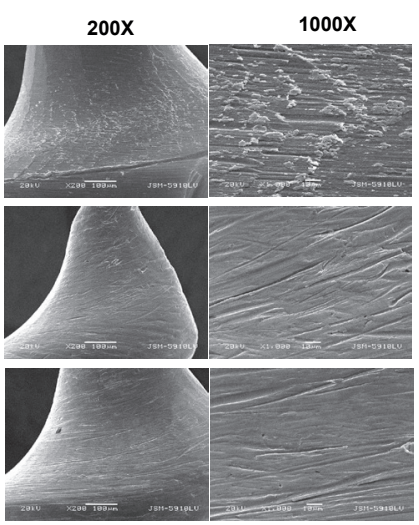

ORTHO EASY
Figure 7. SEM images (200x and 1000x magnification).

\section{Discussion}

Widespread usage of miniscrews has led to better treatment results in critical anchorage cases. In some cases, changing the miniscrew position may be necessary. The possibility of recycling miniscrews would decrease treatment costs and improve treatment results (14). However, there are ethical considerations about the reuse of invasive medical materials among different patients. Nevertheless, especially in cases of early failure, re-insertion of the miniscrew in the same patient may be an option if the materials do not have any structural and functional changes (8). However, expected changes in tip and threads may change the insertion performance of miniscrews during re-insertion. The aim of this study was to assess the impact of insertion and sterilization processes on primary stability, mechanical and surface characteristics of miniscrews.
Primary stability is affected mainly by miniscrew design, bone quality and insertion angle (16-18). To assess primary stability, periotest, resonance frequency analysis, insertion and removal torque measurements and pull-out strength tests have been used in previous research $(5,19,20)$. Periotest and resonance frequency analysis often have low accuracy and values for different screw types may not be comparable (21). Insertion and removal torques and pull out strength tests are the most common methods for assessment of primary stability $(18,22,23)$.

For in-vitro evaluation of primary stability of miniscrews, various bone specimens, such as femurs or ribs of animals, jaws of cadavers or artificial bone materials, have been used previously $(5,24-26)$. Artificial bone materials provide uniform bone thickness and density. They have been used in various studies that have aimed to understand the effects of miniscrew design on primary stability, in order to eliminate bone specimen differences $(19,27)$. In the present study, artificial bone material was preferred to standardize the variables related to bone materials. Having a uniform cortical bone thickness, bone density and a fixed vertical load and direction were advantages in this study design.

Researchers have used several methods for the cleaning process of miniscrews. Mattos et al. used ultrasonic cleaner with an enzymatic detergent (Endozyme), Noorollahian et al. used $37 \%$ phosphoric acid and sodium hypochlorite solution and Estelita et al. used sandblasting with $90 \mu \mathrm{m}$ $\mathrm{Al}_{2} \mathrm{O}_{3}$ particles prior to ultrasonic cleaning $(8,14,15)$. In the present study, there were no tissue remnants attached to the miniscrews because artificial bone was used. However, in order to simulate the cleaning process of used miniscrews, ultrasonic cleaning with Endozyme was performed.

Many researchers investigating the effects of screw diameter have reported that an increase in screw diameter increased primary stability $(5,28)$. In addition, lijima et al. showed that miniscrews of smaller diameter were less resistant to torsional forces (29). In the present study, miniscrews of similar diameters were used. Surprisingly, the fracture torque values were found to be lower in the OrthoEasy miniscrews. This could have been due to the thinner inner diameter of the OrthoEasy miniscrews and it was observed that fracture occurred at the thinnest part of the middle third of the threaded region.

Manystudies havecompared the primarystability of different kinds of miniscrews, but few have evaluated the primary stability of reused miniscrews. The insertion and removal torque values of the OrthoEasy miniscrews were significantly higher than those of DualTop miniscrews. Maximum insertion torque values are created at the neck region of miniscrews. The torque values of the OrthoEasy miniscrews were higher because the neck region of OrthoEasy miniscrews are thicker. The insertion torque values of the reused miniscrews were lower than those of the new miniscrews. This finding could be due to abrasion and smoothening of the surface that was observed in SEM analysis. The mean removal torque values of reused miniscrews were also decreased but the difference was not statistically significant. No statistically significant difference was determined in the resistance test results. When all the parameters of primary stability were compared together, it was concluded that the difference between the twice-used and new miniscrews in respect of primary stability was not significant. 
One of the most dangerous scenarios of miniscrew failure is breakage of miniscrew during insertion or removal. Mattos et al. found a statistically significant decrease in the fracture torque values of the reused miniscrews and it was concluded that reuse of miniscrews should not be recommended, although fracture torque values were higher than the insertion torque values suggested by Motoyoshi et al. $(8,17)$. In contrast, Noorollahian et al. and Estelita et al. found no difference between new and reused miniscrews $(14,15)$. The fracture torque values of the present study were consistent with the findings of the studies by Noorollahian et al. and Estelita et al.

Microscopic evaluation of reused miniscrews is crucial for assessment of structural changes. Chatzigianni et al. and Mattos et al. showed that there were no alterations in material structure, such as corrosion, cracks or defects on reused miniscrews $(5,8)$. However, Mattos et al. observed smoothening of threads, atrophy of the tip region and scratches on reused miniscrews (8). In the present study, the same alterations were observed in reused miniscrews. It can be thought that alterations in the tip and threads would change insertion performance of miniscrews during reinsertion but these alterations made no significant difference in the second insertion of the used miniscrews. However, the decrease in insertion torque value was significant after the second insertion.

\section{Conclusion}

Although wear and atrophy were seen in used miniscrews, the overall primary stability and fracture torque resistance did not show a significant change after the second insertion. It should be kept in mind that there are ethical considerations about the re-use of invasive medical materials among different patients and this study evaluated in-vitro changes in miniscrews up to the second re-insertion procedure. Within the limits of this study, it can be concluded that miniscrews can be re-inserted, especially in early failure cases, for a second time without a significant change in their mechanical and structural properties, but only if cleaning and sterilization processes are applied methodically.

\section{Ethics committee approval: Not required}

Informed consent: Not required.

Peer review: Externally peer-reviewed.

Author contributions: $\mathrm{CAH}$ and NK participated in designing the study. CAH and MA participated in generating the data for the study. $\mathrm{CAH}$ participated in gathering the data for the study. MA participated in the analysis of the data. CAH and YBA wrote the majority of the original draft of the paper. YB participated in writing the paper. All authors approved the final version of this paper.

Conflict of interest: The authors have no conflicts of interest to declare.

Financial disclosure: This study was supported by Marmara University Scientific Study Projects Unit (BAPKO) with project number: SAG-C-DRP-040712-0266.

Türkçe öz: Yerleştirme ve sterilizasyon işlemlerinin minividaların mekanik ve yüzey özellikleri üzerindeki etkilerinin in-vitro olarak incelenmesi. Amaç: Çalışmanın amacı, yerleştirme ve sterilizasyon işlemlerinin minividaların mekanik ve yüzey özellikleri üzerindeki etkilerinin incelenmesidir.Gereç ve yöntem: 140 minivida (70 DualTop; 70 Ortho-Easy) 3 gruba ayrılmıştır. Grup 1: kontrol grubu; her iki markadan 10'ar adet minivida herhangi bir işlem uygulanmadan incelenmiştir. Grup 2 ve Grup 3: çalışma gruplarl; her iki markadan 30'ar minivida. Grup 2'de minividalar yapay kemik bloğuna bir kez yerleştirilip sterilize edilerek test edilmiştir. Grup 3'de minividalar yapay kemik bloğuna iki kez yerleştirilip çıkarılmış; her yerleştirilme sonrası sterilizasyon işlemleri yinelendikten sonra testler uygulanmıştır. Minividalar primer stabilite, mekanik özellikler ve yüzey özellikleri açısından Taramalı Elektron Mikroskobu analizi, burulma testi, maksimum yerleştirme ve çıkarma torku, yatay ve dikey çekme kuvveti testleri ile değerlendirilmiştir. Bulgular: Grup 1'in maksimum yerleştirme tork değerleri Grup 2 ve 3'e göre anlamlı şekilde yüksek bulunmuştur $(p<0.05)$. Ancak çıkarma torku, yatay ve dikey çekme kuvveti ve burulma direnci değerlerindeki değişim istatistiksel olarak anlamlı bulunmamıştır. Taramalı elektron mikroskobu analizinde, Grup 2 ve 3'te minividaların özellikle apikal bölgelerinde aşınma olduğu ve kaplamalı minividaların oksit tabakasının kısmen kaybolduğu gözlemlenmiştir. Sonuç: Çalışma grubu minividalarının taramalı elektron mikroskobu analizinde aşınma ve atrofi gözlenmesine rağmen mekanik testlerde kontrol grubu ile arasında anlamlı bir fark bulunmamıştır. Anahtar kelimeler: minivida; ortodontik mini-implant; primer stabilite; taramalı elektron mikroskobu; sterilizasyon.

\section{References}

1. Tsui WK, Chua HD, Cheung LK. Bone anchor systems for orthodontic application: a systematic review. Int J Oral Maxillofac Surg. 2012;41(11):1427-38. [CrossRef]

2. Park H-S, Yoon D-Y, Park C-S, Jeoung S-H. Treatment effects and anchorage potential of sliding mechanics with titanium screws compared with the Tweed-Merrifield technique. Am J Orthod Dentofacial Orthop. 2008;133(4):593-600. [CrossRef]

3. Geron S, Shpack N, Kandos S, Davidovitch M, Vardimon AD. Anchorage loss--a multifactorial response. Angle Orthod. 2003;73(6):730-7.

4. Gainsforth BL, Higley LB. A study of orthodontic anchorage possibilities in basal bone. Am J Orthod Oral Surg. 1945;31(8):406-17. [CrossRef]

5. Chatzigianni A, Keilig L, Reimann S, Eliades T, Bourauel C. Effect of mini-implant length and diameter on primary stability under loading with two force levels. Eur J Orthod. 2011;33(4):381-7. [CrossRef]

6. Giancotti A, Arcuri C, Barlattani A. Treatment of ectopic mandibular second molar with titanium miniscrews. Am J Orthod Dentofac Orthop. 2004;126(1):113-7. [CrossRef]

7. Baumgaertel S. Quantitative investigation of palatal bone depth and cortical bone thickness for mini-implant placement in adults. Am J Orthod Dentofacial Orthop 2009;136(1):104-8. [CrossRef]

8. Mattos $C T$, Ruellas ACDO, Elias $C N$. Is it possible to re-use miniimplants for orthodontic anchorage? Results of an in vitro study. Mater Res. 2010;13(4):521-5. [CrossRef]

9. Buckthal JE, Kusy RP. Effects of cold disinfectants on the mechanical properties and the surface topography of nickel-titanium arch wires. Am J Orthod Dentofac Orthop. 1988;94(2):117-22. [CrossRef]

10. Lee SH, Chang Y II. Effects of recycling on the mechanical properties and the surface topography of nickel-titanium alloy wires. Am J Orthod Dentofac Orthop. 2001;120(6):654-63. [CrossRef]

11. Bahnasi Fl, Rahman ANAA, Abu-Hassan MI. The impact of recycling and repeated recycling on shear bond strength of stainless steel orthodontic brackets. Orthod Waves. 2013;72(1):16-22. [CrossRef]

12. Kapila S, Sachdeva R. Mechanical properties and clinical applications of orthodontic wires. Am J Orthod Dentofac Orthop. 1989;96(2):100-9. [CrossRef] 
13. Acar YB, Hergel $C A$, Ateş $M B$, Küçükkeleş N. Mini-implant usage in orthodontic practice. Turkish J Orth. 2015;28(1):1-6. [CrossRef]

14. Noorollahian S, Alavi S, Monirifard M. A processing method for orthodontic mini-screws reuse. Dent Res J (Isfahan). 2012;9(4):447-51.

15. Estelita S, Janson G, Chiqueto K, Ferreira ES. Effect of recycling protocol on mechanical strength of used mini-implants. Int J Dent. 2014;2014:424923. [CrossRef]

16. Kim S-H, Lee S-J, Cho I-S, Kim S-K, Kim T-W. Rotational resistance of surface-treated mini-implants. Angle Orthod. 2009;79(5):899907. [CrossRef]

17. Motoyoshi $M$, Hirabayashi $M$, Uemura $M$, Shimizu $N$. Recommended placement torque when tightening an orthodontic mini-implant. Clin Oral Implants Res. 2006;17(1):109-14. [CrossRef]

18. Wilmes B, Rademacher C, Olthoff G, Drescher D. Parameters affecting primary stability of orthodontic mini-implants. J Orofac Orthop. 2006;67(3):162-74. [CrossRef]

19. Song Y-Y, Cha J-Y, Hwang C-J. Mechanical Characteristics of Various Orthodontic Mini-screws in Relation to Artificial Cortical Bone Thickness. Angle Orthod. 2007;77(6). [CrossRef]

20. Kim J-W, Ahn S-J, Chang Y-I. Histomorphometric and mechanical analyses of the drill-free screw as orthodontic anchorage. Am J Orthod Dentofacial Orthop. 2005;128(2):190-4. [CrossRef]

21. Mischkowski R a, Kneuertz P, Florvaag B, Lazar F, Koebke J, Zöller JE. Biomechanical comparison of four different miniscrew types for skeletal anchorage in the mandibulo-maxillary area. Int J Oral Maxillofac Surg. 2008;37(10):948-54. [CrossRef]
22. Carano A, Lonardo P, Velo S, Incorvati C. Mechanical properties of three different commercially available miniscrews for skeletal anchorage. Prog Orthod. 2005;6(1):82-97.

23. Kido H, Schulz E, Kumar A, Lozada J. Implant diameter and bone density: effect on initial stability and pull-out resistance. J Oral Implantol. 1997;23:163-9.

24. Pithon MM, Nojima MG, Nojima LI. In vitro evaluation of insertion and removal torques of orthodontic mini-implants. Int J Oral Maxillofac Surg. International Association of Oral and Maxillofacial Surgery; 2011;40(1):80-5. [CrossRef]

25. Pickard MB, Dechow P, Rossouw PE, Buschang PH. Effects of miniscrew orientation on implant stability and resistance to failure. Am J Orthod Dentofacial Orthop. American Association of Orthodontists; 2010;137(1):91-9.

26. Cho K-C, Baek S-H. Effects of predrilling depth and implant shape on the mechanical properties of orthodontic mini-implants during the insertion procedure. Angle Orthod. 2012;82(4):61824. [CrossRef]

27. Wang C-H, Wu J-H, Lee K-T, Hsu K-R, Wang HC, Chen C-M. Mechanical strength of orthodontic infrazygomatic miniimplants. Odontology. 2011;99(1):98-100. [CrossRef]

28. Lim S-A, Cha J-Y, Hwang C-J. Insertion torque of orthodontic miniscrews according to changes in shape, diameter and length. The Angle orthodontist. 2008;78(2):234-40. [CrossRef]

29. lijima M, Muguruma T, Brantley WA, Okayama M, Yuasa T, Mizoguchi I. Torsional properties and microstructures of miniscrew implants. Am J Orthod Dentofacial Orthop. 2008;134(3):333. [CrossRef] 